\title{
UM OLHAR PRISMÁTICO SOBRE A CRIAÇÃO DE NARRATIVAS PUBLICITÁRIAS
}

\author{
CARRASCOZA, João Anzanello. Estratégias criativas da \\ publicidade: consumo e narrativa publicitária. São Paulo: \\ Estação das Letras e Cores, 2014. 176 p
}

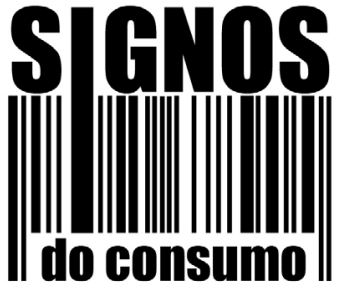

resenha

\author{
Renato Gonçalves \\ Universidade de São Paulo, São Paulo, Brasil. \\ Doutorando em Ciências da Comunicação pela Escola de Comunicações e Artes (ECA) da Universidade de \\ São Paulo (USP) e mestre em Culturas Brasileiras pelo Instituto de Estudos Brasileiros (IEB) da USP. Membro \\ do Grupo de Estudos Semióticos em Comunicação, Cultura e Consumo (GESC3) da ECA-USP. \\ E-mail: renatogoncalves@usp.br
}

Conta a história que, certa vez, impossibilitado de visitar a virgem Dânae, Zeus se transfomou em gotas de ouro para invadir, pelas frestas do telhado, sua torre. A partir de uma narrativa mítica grega, João Anzanello Carrascoza abre Estratégias criativas da publicidade (2014) para trabalhar a ideia de que a publicidade pode ser compreendida não somente como uma das possíveis estratégias para vender produtos ou serviços, mas também como algo a ser consumido enquanto "ficcionalidade" e penetrar, assim como as gotas de ouro, o "ubíquo e onipresente" sistema midiático. Tendo como ponto de partida a dimensão estética das expressões publicitárias, o autor mobiliza um arsenal teórico advindo da crítica literária, da comunicação, da filosofia e dos estudos do consumo para compreender e evidenciar, em uma perspectiva contemporânea e prismática, estruturas narrativas próprias à publicidade.

Já no segundo capítulo de seu livro, "Publicidade de bens de consumo e de serviços espirituais, o mesmo texto", Carrascoza empreende um estudo comparativo para apontar o uso da retórica da emoção. Dissecando dois textos de origens distintas, o autor elenca alguns de seus traços em comum. Em ambos, por exemplo, são reproduzidas as quatro fases da narrativa defendidas por José Luiz Fiorin: manipulação, competência, performance e sanção. Para delinear um dos possíveis cânones publicitários, escolha lexical, figuras de linguagem, estereótipos, uso de testemunhais e indícios da função conativa também são elementos explícitos enquanto procedimentos de persuasão.

Em se tratando da publicidade destinada aos publicitários, vertente usualmente deixada de lado nos estudos de comunicação, Carrascoza, no terceiro capítulo, "A ironia como tática para contagiar o público consumidor", retoma, partindo de Umberto Eco e Eni Orlandi, a discussão entre emissor e destinatário na mensagem publicitária. Analisando anúncios de uma gráfica e do Clube de Criação de São Paulo, o autor diferencia os dois tipos possíveis de leitor de conteúdos publicitários: os semânticos, que estariam interessados em acompanhar uma narrativa do começo ao fim para saber o que nela acontece, e os semióticos, que, diante da narrativa, desejam compreender como o que acontece é narrativamente estruturado. Este último ponto justificaria o constante uso da ironia enquanto um recurso retórico da publicidade voltada aos publicitários. 
Aproximando-se da literatura, Carrascoza, no quarto capítulo, discorre acerca do "detalhe expressivo" na criação publicitária. Partindo da construção realista de Gustave Flaubert, do século XIX, o autor vai apontar, em alguns anúncios, como a cena do consumo é construída a partir de pequenos detalhes que fazem toda a diferança na narrativa publicitária. No clássico vídeo de cerveja Heineken, o compositor de blues que se vê diante da dificuldade de compor uma nova canção, ao abrir uma cerveja, reativa seu potencial criativo - uma narrativa audiovisual desenvolvida no antes e no depois da inserção da cerveja. Nessa direção, Carrascoza (p. 51) é assertivo ao dizer que "a publicidade mimetiza a estratégia do romance realista, valendo-se em suas narrativas, desses detalhes técnicos, importantes e insignificantes”.

No quinto capítulo, o pesquisador percorre possíveis respostas para uma pergunta que ronda os estudos que buscam relacionar a publicidade e o consumo: "como a publicidade produz o sonho de consumo?". Retomando Jean Baudrillard, Everardo Rocha e André Péninou, o autor discute os encontros e os desencontros entre o real e o mundo da publicidade. Dentro do sistema midiático, a publicidade estaria a serviço da construção do mundo ideal, favorável e preferível. Regulando o próprio sistema em que opera, as expressões publicitárias seriam a porta de entrada para inserir o consumidor no ambiente do consumo.

Em "Do anúncio clássico à guerrilha publicitária”, capítulo que se segue, Carrascoza lança um olhar em retrospectiva sobre a história da publicidade buscando identificar o detalhe como elemento constitutivo das narrativas publicitárias. Do período da Belle Époque, o autor destaca a forma de empilhamento visual nos cartazes de Toulouse-Lautrec, nos quais a cena do consumo é ambiente para personagens. No processo evolutivo da publicidade, os anúncios classificados nos jornais, de início, exploravam a enumeração de características do produto ou do serviço anunciados, técnica persuasiva que logo daria lugar aos benefícios que o objeto anunciado poderia proporcionar ao leitor. Em paralelo, dois tipos de publicidade vão se mesclando: o que dá destaque às imagens e aquele que enfatiza as palavras. $O$ detalhe narrativo, assim, foi sendo explorado também no intercruzamento entre as matrizes verbais e visuais. No amadurecimento dessa práxis criativa, Carrascoza vai destacar três publicitários que viriam a transformar a publicidade moderna: Leo Burnett, que fez uso de personagens e navegou pelos núcleos de fabulação das marcas; Bill Bernbach, que desenvolveu formações discursivas inusitadas e até então disfóricas, como a complexa relação minimalista entre imagem e texto nos clássicos anúncios da montadora de carros VW; David Ogilvy, que usou com maestria o detalhe expressivo como forma catalisadora de mensagens publicitárias.

Ainda no extenso sexto capítulo, Carrascoza vai dar pistas das características intrínsecas ao bom profissional de criação publicitária. Trazendo para a discussão textos em que evidencia a ingenuidade e a reflexão como forças motrizes para a divulgação de produtos e serviços, o autor relembra a dupla jornada de escritores e artistas que, na historiografia da área, se dividiam entre a criação artística e a criação voltada ao consumo. Na trajetória da publicidade, artistas visuais, poetas e romancistas venderam sua força de trabalho para a publicidade, emprestando para a produção publicitária suas técnicas de criação e enriquecendo o modus operandi criativo. Para encerrar a discussão acerca da linha histórica da publicidade, o autor destaca a publicidade 
de guerrilha como a evolução técnica do uso do detalhe expressivo para direcionar o olhar do leitor na narrativa publicitária.

Em "Poesia: um diferencial para a produção e o consumo de publicidade", sétimo capítulo, o autor adentra a seara da criação poética para defender a ideia de que "é possível olhar a publicidade pelo prisma da poesia" (CARRASCOZA, p. 135). Para sustentar sua argumentação, Carrascoza elenca algumas peças publicitárias que desafiam o status quo retórico, como as campanhas da Benetton e da Diesel que, a partir de formações discursivas não convencionais, operam com valores disfóricos para contrapor-se e diferenciar-se da hegemonia discursiva publicitária vigente.

No penúltimo capítulo, Carrascoza vai apontar os ditos e os não ditos da publicidade a partir da análise de anúncios que utilizam a comparação como um recurso retórico. Indo além da ideia de que a publicidade dialoga com o seu contexto, o autor evidencia, a partir de Oswald Ducrot, as duas formas do não dizer: o pressuposto e o subentendido. Realizando a análise de anúncios que promovem a Folha de S.Paulo, o autor mapeia as múltiplas direções que seus enunciados podem tomar, deixando implícitas características que abonam a marca quando comparada aos seus concorrentes. Os não ditos, prova o autor, são parte constitutiva da publicidade e podem revelar muito mais que os próprios ditos.

Encerrando, Carrascoza retoma a ideia inicial do livro: a publicidade é uma narrativa ficcional a ser consumida. Indo além da usual e já banalizada concepção de storytelling, o autor defende a construção de boas histórias para gerar empatia com a audiência e dialogar com um contexto mais amplo que a própria expressão publicitária. Para tal, devemos nos valer de estratégias criativas já desenvolvidas, tanto no curso da historiografia da publicidade quanto a partir do olhar às áreas adjacentes, como a literatura. Dentro do contexto midiático, a publicidade pode ser a chuva de ouro, outrora evocada pela mitologia grega, que penetra as frestas do imaginário coletivo e o alimenta com imagens, valores e narrativas. 